Meta

Journal des traducteurs

Translators' Journal

\title{
The Terminology of Translation
}

\section{Roda P. Roberts}

Volume 30, numéro 4, décembre 1985

URI : https://id.erudit.org/iderudit/003961ar

DOI : https://doi.org/10.7202/003961ar

Aller au sommaire du numéro

Éditeur(s)

Les Presses de l'Université de Montréal

ISSN

0026-0452 (imprimé)

1492-1421 (numérique)

Découvrir la revue

Citer cet article

Roberts, R. P. (1985). The Terminology of Translation. Meta, 30(4), 343-352.

https://doi.org/10.7202/003961ar

Ce document est protégé par la loi sur le droit d'auteur. L'utilisation des services d'Érudit (y compris la reproduction) est assujettie à sa politique d'utilisation que vous pouvez consulter en ligne.

https://apropos.erudit.org/fr/usagers/politique-dutilisation/ 


\section{ÉTUDES TERMINOLOGIQUES ET LINGUISTIQUES}

\section{THE TERMINOLOGY OF TRANSLATION}

The word "terminology" is often associated with translation for several reasons. Firstly, translators are major users of terminology ${ }^{1}$, in the sense of the technical or special terms or expressions used in a given discipline, profession or activity. Secondly, terminology, as a method of collecting, grouping together and structuring sets of terms peculiar to given subject areas, was developed and practised largely by translators, at least in Canada, in the 50's and 60' ${ }^{2}$. Even today, all translators are expected to be able to do terminological research and all translator training programmes include at least one course on this subject ${ }^{3}$.

Ironically, however, these translator/terminologists who have helped develop the nomenclature of areas as diverse as solar energy, the police force and public transportation, have paid little or no attention to the terminology of their own primary field of activity, translation. Not only is there no published, and thus official, lexicon of translation terms, at least to my knowledge, but there are relatively very few glossaries attached to works on translation ${ }^{4}$.

The lack of such glossaries or lexicons would not, in itself, constitute a problem if the terminology of translation, in its present state, fully satisfied the expressive and communicative needs of its users (translators, translation scholars, translation students, translation customers) and allowed them to be able to discuss translation without possibility of ambiguity or confusion. However, this is far from being the case.

The very term " translation" is itself ambiguous, for it is used both as a "general term referring to the transfer of thoughts and ideas from one language (source) to another (target), whether the languages are in written or oral form", and as a more specific terme referring to the transfer of written input, in opposition to "interpretation" which designates the transfer of oral input (Brislin 1976:1). Again, this in itself would not pose a problem if usage were systematic, i.e. if "translation" used by itself always designated the transfer of both written and oral input, and, when used along with "interpretation" in the same discussion, designated the more specific transfer of written input. However, this is not always, nor even generally, the case as the following context shows :

Interpreters invariably use meaning as their basis, for they are aware that their translation would be lacking in effectiveness if they were to take the linguistic code only. (Seleskovitch $1976: 109)$

In this context, "interpreters" clearly designates those who orally transfer a message from one language to another ; thus "translation" refers here to oral output and not written output.

The polysemy of the term "translation"5 is beginning to be matched by that of the term "interpretation". While "interpretation" or "interpreting" as a technical term in the discipline of translation has long been used to designate "oral translation", it is now also used in translation literature to cover concept of linking linguistic units to relevant 
knowledge (i.e. the idea of understanding fully). It is in this second technical sense that "interpretation" is used throughout the five hundred pages of George Steiner's After Babel. Aspects of Language and Translation, in which there is no reference to "interpretation" in the sense of "oral translation". The two very different technical senses attached to the term "interpretation" or "interpreting" in the general field of translation allows for such plays on words as "Interpretation, a Psychological Approach to Translating", which is the title of an article by Danica Seleskovitch treating "interpretation" in both technical senses, as well as translation in the narrower sense of written transfer.

It is apparent, from the couple of terms discussed above, that polysemy poses a problem in that it can lead to confusion, and often does, especially in languages for special purposes. That is why a much sought-after characteristic in specialized vocabularies is "univocity" or "monosemy", with each designation referring to a single concept, which is related to a single referent :

un signifiant $\longrightarrow$ un signifié $\longrightarrow$ un référent $t^{6}$

However, polysemy is an intrinsic feature of language 7 , which cannot be avoided in the interest of the economy of a language, and many, if not most, words, whether general or specialized, express several different concepts and are thus related to a variety of referents :
un signifiant

signifié
signifié
signifié
référent $\rightarrow a$
référent $\rightarrow b$
référent $\rightarrow c^{8}$

To solve the theoretical dilemma posed to them by polysemy, terminologists have adopted a stratagem, also used by a few lexicographers 9 . Instead of considering "interpretation", for instance, as a designation covering more than one concept, as polysemous (one word with several meanings), they would argue that "interpretation" is really two different terms, each monosemous, which happen to have the same designation, i.e. that we are dealing with homonymy ${ }^{10}$. However, whether we call the phenomenon polysemy or homonymy does not change the fact that confusion can result from it.

Confusion is less, or even non-existent, when the designation covers very different concepts in very distinct fields : e.q. "éther" designates "partie la plus haute de l'atmosphère" in literature, "milieu physique hypothétique" in physics, and "classe de matières chimiques" in chemistry, and since the three different concepts would rarely be presented in the same text or discourse, misunderstanding would be surprising. However, a term like "translation", whose two technical senses presented above pertain to the same field and are so similar, poses a serious problem of comprehension, even to specialists in the field, because it is "equivocal"11. And "translation" and "interpretation" are far from being the only translation terms which have more than one meaning within the discipline of translation itself.

Another phenomenon that causes problems of comprehension in the literature on translation is that of synonymy, i.e. several different designations covering the same concept and indicating the same referent :

$$
\begin{array}{ll}
\text { signifiant } & \mathrm{a} \\
\text { signifiant } & \mathrm{b} \rightleftharpoons \\
\text { signifiant } & \mathrm{c}
\end{array} \text { un concept } \longrightarrow \text { un référent }{ }^{12}
$$

There has been much discussion of the difference between synonymy in general language (where a slight difference in nuance between two synonyms is less important than the stylistic resource they offer $)^{13}$ and synonymy in languages for special purposes (where two terms that differ in nuance, even if they do cover the same concept, must be clearly distinguished and cannot therefore really be considered as synonyms ${ }^{14}$, but where synonyms are terms that cover exactly the same concept but are distinguished by 
different circumstances of use - geographical, chronological, professional, commercial, etc.). However, the terminology of translation includes mainly synonyms of the first type : "synonyms" with slight differences in meaning.

For instance, Catford's "level shift" can be considered a synonym of what Vinay and Darbelnet term "transposition"15 on the basis of examples used by each to clarify the concept covered :

This text is intended for...

$L e$ présent manuel s'adresse à...

(Catford $1974: 75$ )

Reports here indicate that...

D'après les informations reçues ici...

(Vinay \& Darbelnet 1958 : 98)

In each case, there has been a change in the part of speech (in italics) in the example; hence, one may well deduce that both "level shift" and "transposition" designate a change in parts of speech during transfer of a message. However, a more detailed study indicates that Catford would not accept all Vinay \& Darbelnet's examples as "level shift", since for him this designates, not all changes in parts of speech, but only a shift from grammar to lexis and vice versa. Hence a change from verb to noun, as in another example of transposition provided by Vinay \& Darbelnet ("as soon as he gets up/dès son lever"), would not constitute a level shift, but a change from demonstrative to lexical adjective, even if it is preceded by an article, would. Thus, while "transposition" and "lexical shift" can be considered generally as synonyms, there is a slight difference in meaning nuance between them, a nuance that can easily be overlooked without careful study.

Other terms that are generally synonymous but do nevertheless contain slight differences in meaning abound in the field of translation : e.g. "literal translation" and "word-for-word translation" are both generally used to cover translation that sticks too closely to the form of the original, but in certain cases an additional distinction is made, with the former covering phrase-for-phrase translation and the latter literally word-forword and often morpheme-for-morpheme translation ${ }^{16}$.

In many cases, synonyms in the field of translation seem to derive from the different "schools of thought" that influence translation scholars, i.e. from their different "educational" backgrounds. Thus, what many translation scholars term "(linguistic) context" (items in a text that accompany the item under discussion), Catford, influenced by Firthian linguistics, calls "co-text".

The fact that Catford uses "co-text" where others would use "(linguistic) context" would not, in itself, pose a problem once the link co-text = (linguistic) context were made. However, what makes for further complications is the fact that he uses the term "context", alongside "co-text", but in a different sense from a number of translation scholars :

By context we mean "context situation", i.e. those elements of the extra-textual situation which are related to the text as being linguistically relevant. (Catford $1974: 31$ )

This, in turn, leads us to yet another terminological problem in translation : that of the same designation being used by different scholars to cover different concepts. If "context" for Catford means linguistically relevant features of extra-textual situation, "context" for Nida and Taber covers "the total setting in which a word is used, including the cultural context and the linguistic context (Nida \& Taber $1974: 199$ ), whereas for Roberts, it designates all textual elements (Roberts $1982: 126$ ). How then is a reader of 
translation literature to know what each individual author means by a simple word like "context"?

While this problem might seem like just another case of polysemy, it is much more than that, for the different meanings attributed to the term "context" often stem from basic differences in each author's conception of the translation process. For instance, Delisle uses "contexte" as a very broad term covering "contexte linguistique", "contexte référentiel", "contexte cognitif", and "contexte situationnel", for he does not see the role of each as distinct in the translation operation ${ }^{17}$, whereas Roberts, influenced by Darbelnet and Pergnier, makes a clear distinction between "contexte" and "situation", for she sees the two realities as influencing the translation process somewhat differently ${ }^{18}$. Thus, in order to understand what the term "context" or "contexte" means in the writings of each of the authors mentioned above, the reader must grasp the general theoretical framework of each.

Polysemy, synonymy and the influence of different theoretical frameworks on the concept underlying a given term are only three of the major problems in the terminology of translation. These problems are found equally in translation terminology in both English and French, although the terms in which they may be manifested may differ. These terminological problems pose major obstacles to comprehension, not only for neophytes such as translation students, but also to experienced practising translators, who are often so confused by the terminology of the discipline that they reject most works on translation as either incomprehensible or unworthy of attention.

All the problems mentioned above and more are revealed by an analysis of the translation terminology related to meaning. This analysis is based on the works of the following major translation scholars : George Steiner, J.C. Catford, Eugene Nida and Charles Taber, all of whom have written in English, and Jean-Paul Vinay and Jean Darbelnet, Danica Seleskovitch, Jean Delisle, and Maurice Pergnier, whose basic works are in French.

If the terminology related to meaning has been chosen as the subfield for analysis, it is because meaning, however it is defined or designated, is central to any discussion of translation, for it is the focus of the translation process. As Vinay and Darbelnet put it,

Le traducteur (...) part du sens et effectue toutes ses opérations de transfert à l'intérieur du domaine sémantique. (Vinay \& Darbelnet $1958: 37$ )

But what does "meaning" or "sens" mean to these scholars?

To begin with, let us examine the term "meaning" in the works of Nida and Taber, Steiner and Catfort. Nida and Taber have perhaps been the most explicit in their explanation of meaning, although, surprisingly enough, "meaning" per so does not figure in the glossary at the end of The Theory and Practice of Translation, which is supposed to contain all terms that are either inherently technical or have been used by them in a sense other than their everyday sense. A study of the following contexts gives us an idea of their concept of meaning :

Translating consists in reproducing in the receptor language the closest natural equivalent of the source-language message, first in terms of meaning and secondly in terms of style. (Nida \& Taber 1974: 12)

As has already been indicated in the definition of translating, meaning must be given priority, for it is the content of the message which is of prime importance for Bible translating. (Nida \& Taber $1974: 13$ )

From these two contexts we can deduce that meaning is the content of a message, that it is one aspect of a message, the other being style. Elsewhere (Nida \& Taber 1974 : 
34ff.), it is made clear that meaning is manifested through grammar (relationships between words and combinations of words) and through the words and linguistic units themselves, which have referential meaning (which "relates the term to the portion of the nonlinguistic world it symbolizes" - glossary) and connotative meaning (which concerns the emotional reaction that the words provoke). "Meaning" for Nida and Taber is thus something that is both linguistic and nonlinguistic : it is manifested linguistically but expresses what is in the real world. But to fully understand it, one must understand what "message" means, for "meaning" is only a part of message.

For Steiner, on the other hand, "meaning" is a generic term that covers not only the referential, connotative and grammatical meanings of words and their combinations as postulated by Nida, but also what is left unsaid, what is hidden behind the words, what Steiner calls the "total operative context" (Steiner $1977: 6$ ). In fact, "meaning" is something that is so vast for Steiner that nowhere is it explicitly defined ; one only develops an intuition of what the term means to him after wading through hundreds of pages. Steiner admits that "the epistemological and formal grounds for the treatment of 'meaning' as dissociable from and augmentative to "words" by translation theory are shaky at best (Steiner $1977: 277$ ), but proposes no solution to the problem himself in a work that deals essentially with the transfer of meaning.

Contrary to Steiner, Catford, in terms of the Firthian theory of meaning, feels that "the view (...) that 'transference of meaning' occurs in translation in untenable" (Catford 1974 : 35), for "meaning, in our view, is a property of a language". He defines "meaning" as "the total network of relations entered into by any linguistic form", these relations being of two kinds : formal (relations between one formal item and others in the same language) and contextual ("relationship of grammatical or lexical items to linguistically relevant elements in the situations in which the items operate as, or in, texts" - ibid. : 36). By defining "meaning" as a property of a given language, he partially resolves Steiner's dilemma concerning the dissociability of words and meaning, but he also greatly limits the extension of the term.

The necessarily brief analysis of the concepts underlying the term "meaning" as used by Nida and Taber, Steiner, and Catford can be summarized in the following way :

NIDA \& TABER

1. Meaning a part of message

2. Meaning relates the linguistic \& the nonlinguistic

Meaning not tied to language of a language

Meaning $=$ content

5. Meaning fairly vast

\section{STEINER}

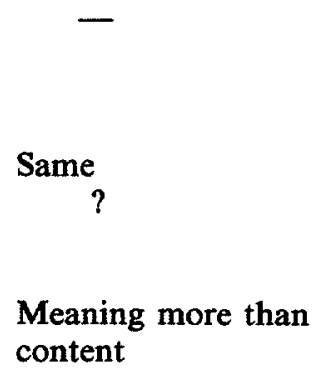

Meaning very vast

\section{CATFORD}

Same
Meaning a property

Meaning seen not in terms of content but in terms of relations

Meaning more limited but complex

This study of the term "meaning" reveals polysemy of the word, but it also shows that the different senses attributed to it are a result of the general theoretical background of each scholar. If Catford's concept of meaning is so particular, it is because he uses Firthian theory ; if Steiner's concept of meaning is so all-embracing, it is because he 
believes in hermeneutics; and if "meaning" is considered a part of "message" by Nida and Taber, it is because they are proponents of the communicative theory of translation in which the "message" is of prime importance.

However, Nida and Taber are not consistent in the distinction that they establish between "meaning" and "message". If, in their definition of translating quoted above, they indicate that message $=$ content + style, elsewhere they seem to almost equate message with meaning as the following context reveals :

Anything that can be said in one language can be said in another, unless the form is an essential element of the message. (Nida \& Taber $1974: 4$ )

In other words, while message may theoretically be a combination of content and style (or form), in reality, in many cases, message content (or meaning). Confirmation of this suspicion is found in the glossary at the end of the work, where "message" is defined as "the total meaning or content of a discourse; the concepts and feelings which the author intends the reader to understand and receive." In fact, if there is any difference between meaning and message, it lies in the level at which meaning is communicated : meaning communicated by smaller units of discourse (words, phrases, perhaps sentences) is called "meaning" ; meaning communicated by larger units of discourse (perhaps sentences, certainly paragraphs and texts) is designated "message". "Meaning" and "message" are thus really almost synonymous in Nida and Taber's terminology.

While the English terminology of meaning is characterized mainly by a specific type of polysemy, with synonymy being limited mainly to "meaning" and "message", the terminology of meaning in French reveals more synonymy. The problem of synonymy is exacerbated by the fact that, instead of having one generic term equivalent to "meaning" in French, most French translation scholars break up the global concept of meaning into several more specific ones, thereby increasing the number of terms covering this global concept and thus the number of synonyms possible.

All of the French translation scholars being studied in this paper use Saussurian linguistics, either directly or indirectly, as their starting point. Since the latter makes a distinction between "langue" (roughly, the system of language) and "parole" (roughly, the individual, concrete use of the system of language for purposes of communication), so do our translation scholars, and since meaning at the level of "langue" must be distinguished from meaning at the level of "parole", the many terms they use to designate meaning fall right away into two major categories : terms used to designate meaning in "langue" and terms used to designate meaning in "parole".

Presented below is an analytical table of the many different terms used for meaning by Vinay and Darbelnet, Seleskovitch, Delisle and Pergnier.

Authors

Vinay \& Darbelnet

Meaning in "langue" signifié

Seleskovitch

signification/

-acceptions

-traits de signification

signification verbale/

signification linguistique
Meaning in "parole"

signification

(for individual signs

sens structural

(for structures)

sens global (for larger

units of discourse)

signification pertinente/

sens des mots

(for individual signs)

sens (du message) (for

larger units of discourse) 
Delisle

Pergnier signifié'

signification/

signification virtuelle/

signification linguistique

[acception] signification pertinente/

sens des mots

et des syntagmes/

[désignation]

(for individual signs)

sens d'un message/

sens d'un énoncél

(for larger units of discourse)

sens (for all units)

signifié acception/

désignation

signification

N.B.

- An oblique line $(/$ after a term means the following term is used as a synonym.

- Terms placed in square brackets are those that are not used often enough for me to be sure of where they stand in relation to the others used by the same author.

- Although Vinay \& Darbelnet, Delisle \& Pergnier also use the Saussurian term "valeur", I have not included it in the table since Seleskovitch does not refer to it. In each case, it is situated in "langue".

The first point that this table reveals is the fact that not only do different translation scholars use different terms to designate more or less the same concept, but that certain authors contribute further to the problem of synonymy by using several different terms synonymously themselves. Moreover, the greatest users of synonyms, Seleskovitch and Delisle, do not facilitate the task of their readers either by establishing where these links would be revealed. The similarity of the concepts covered by Delisle's synonymous terms "signifié" and "signification", for example has to be guessed at from contexts such as the following :

La saisie des signifiés, indépendamment du contenu référentiel qu'ils symbolisent, est une opération de décodage s'opérant par référence au système linguistique. Cette opération a pour but de dégager le contenu conceptuel des mots par une analyse lexico-grammaticale. La connaissance du lexique de la langue anglaise permet au traducteur de convoquer dans sa mémoire la signification individuelle des termes de l'énoncé The Icy Grip Tightens. (Delisle $1980: 71)$

And even if this context, which is far from "defining", does help the reader finally understand that "signifié" and "signification" are really synonyms, it appears a bit late in the work for his purposes.

Another real problem revealed by the table above is that, in certain cases, the same designation is used by several different authors to designate totally different, and sometimes opposed, concepts. This is the case with "signification", which Vinay and Darbelnet use to denote the meaning of a sign in context, in "parole" ("La signification est le sens d'un signe dans un contexte donné" — Vinay \& Darbelnet 1958 : 30), while Seleskovitch and Delisle use it to denote the meaning of a sign out of context, in "langue" ("Tout mot analysé au niveau de la langue, c'est-à-dire hors contexte, possède une signification ou un ensemble de significations (...)" — Seleskovitch 1975 : 11 ; "Nous dirons que la signification $d$ 'un mot est ce à quoi il renvoie dans le système abstrait de la 
langue" - Delisle $1980: 58$ ). What adds to the confusion caused by these diametrically opposed concepts being covered by the same term "signification" is the fact that for Pergnier this term designates, not meaning in "langue" globally — which he calls "signifié", but a specific aspect of meaning in "langue", that aspect that constitutes a semantic invariant :

Si hétéroclite (...) que soit le contenu du signifié de ce mot - saisi du seul point de vue des objets qu'il désigne - il n'est pas moins le signifié d'un seul mot français, et à ce titre, est saisi par le sujet de langue française comme comportant une unité interne, c'est-à-dire comme comportant une "signification" unique et constante, un invariant sémantique. (Pergnier $1980: 185)$

The same type of problem seems to arise with "désignation" as used by Pergnier and Delisle and with "acception" as used by Pergnier and Seleskovitch on the one hand and by Delisle on the other. However, since Delisle uses both "acception" and "désignation" infrequently and does not define them clearly, it is difficult to estimate the extent of the problem.

The lack of clear definitions or the use of other poorly defined terms in definitions compounds the problems posed by polysemy and synonymy. The following context, designed to provide definitions, reveals why, for instance, it is difficult to understand whether Delisle's "acception" is a constitutent of "signification", as Seleskovitch clearly indicates $(1975: 11)$ or whether it is a pure synonym of "signification".

Nous dirons que la signification d'un mot est ce à quoi il renvoie dans le système abstrait de la langue. Tout mot peut avoir plus d'une signification. Ces diverses "acceptions" sont perceptibles hors contexte, c'est-à-dire indépendamment de toute énonciation concrète, et c'est pourquoi il est possible de les compiler dans les ouvrages lexicographiques. (Delisle 1980 : 58)

Another point that the table of French terms of meaning brings to light is the fact that meaning and message are interrelated not only in English but also in French. The distinction between the two seems clearer at first sight in French, for our French translation scholars have related "message" clearly to meaning in "parole" and not in "langue", and we can thereby deduce that while meaning is found in both "langue" and "parole", message exists only at the level of "parole". But neither Delisle nor Seleskovitch seem to feel the need to define "message". And Darbelnet's definition of "message" as "l'ensemble des significations de l'énoncé" (glossary) seems to equate with Nida's definition of "message" as the total meaning of a discourse. Even Pergnier, who has a full chapter on message, does not clearly distinguish between meaning in "parole" and message, as the following paragraph reveals :

Sauf exceptions, les énoncés linguistiques qui constituent les signifiés des messages à traduire ne sont pas univoques et sont susceptibles de traductions multiples, selon les conditions dans lesquelles ils sont émis. C'est-à-dire que le sens d'un énoncé est étroitement solidaire des conditions de son émission. La traduction ne devrait donc jamais porter sur un énoncé en tant que tel (opération qui aboutit non à une véritable traduction mais à une interférence de systèmes) mais sur un message.

$L a$ situation d'émission, qui confêre son sens au message et conditionne son énonciation, se laisse elle-même réduire d̀ une analyse selon quatre paramètres que nous examinerons successivement : ['émetteur, l'objet, le destinataire et le vecteur]. (Pergnier 1980 : 50)

What he seems to be saying here is that a linguistic unit, once it is placed in situation, takes on meaning in "parole" and becomes a "message", that in fact the same conditions (source, object, intended receptor, and vector) are needed for a linguistic unit to take on meaning in "parole" and to become a message. In the long run, therefore, the idea of 
"message" and the difference between it and meaning does not seem much clearer in French than in English.

And with the problems inherent in the terminology of meaning in English and in French and the different areas of meaning covered by the key terms in each language, the translation of texts on translation from one of these languages to the other becomes a very tricky exercise. However, before a good bilingual lexicon of the terminology of translation can be established, much work to be done on the terminology of translation in each language.

First, the entire terminology of each translation scholar needs to be identified, categorized by subfield and clarified by terminological definitions (to compensate for the authors' poor definitions) and contexts. Then, the terminology of each subfield found in various works needs to be analyzed, always bearing in mind the authors' theoretical bias. Only then can we hope to begin compiling a terminology of translation for each language.

Meanwhile, in the hope that translation scholars will take need, I would like to make the following recommendations to them. If an existing term covers the concept you have in mind, it is better, in the interests of communication, to use that term, rather than create your own. For the time being, at least until the terminology of translation is clarified, if not standardized, define carefully all terms that you use, either in the text itself or in a glossary (preferably in both). Above all, bear in mind that writing on translation is a form of technical writing, in which stylistic resources such as synonyms should be sacrificed in favour of clarity and ease of comprehension.

If these simple recommendations are put into practice in future works on translation and if, for works that already exist, other terminological studies such as this one are conducted, we, translator/terminologists, may be able to produce, within a decade, a sound bilingual lexicon of translation terms. And - what is even more important - we will finally be able to communicate with each other on the subject of translation without the constant risk of misunderstanding each other.

\section{Notes}

1. Juan Carlos Sager, in a paper entitled "Training in Terminology : Needs, Achievements and Prospectives in the World" (in Actes du Colloque international sur l'enseignement de la terminologie, Québec, Éditeur officiel du Québec, 1981, pp. 93-123) divides terminology users into two main categories : subject specialists and translators/interpreters.

2. Jean Delisle, in the work $A u$ cœur du trialogue canadien. Croissance et évolution du Bureau des traductions du gouvernement canadien : 1934-1984 (Ottawa, Secretary of State, 1984), recounts that in January 1953 federal government translators, as members of the Association technologique de langue française d'Ottawa (ATLFOO), set up a lexicology centre in premises made available to them by the Superintendant of the Translation Bureau, and that these pioneer, voluntary efforts on the part of translators led to the establishment, later the same year, of the first official terminology service in Canada. The contribution of translators to the early development of terminology is, moreover, not unique to Canada, according to Juan Carlos Sager (op. cit.).

3. For specific information on the teaching of terminology in translator training programmes, see Roda $P$. Roberts (1985) : "The Teaching of Terminology and Documentation in Canadian Universities", TermNet News, September, pp. 77-83.

4. Of the ten or twelve major works on translation in English and French, only two contain a glossary : JeanPaul Vinay and Jean Darbelnet's Stylistique comparée du français et de l'anglais (Paris, Didier, 1958), and Eugene Nida and Charles Taber's The Theory and Practice of Translation (Leiden, E.J. Brill, 1974).

5. I have not discussed all technical senses of translation, in the interest of brevity. However, it must be noted that in addition to the process of transfer, the term "translation" also refers to the product of such a process and to the discipline or professional activity dealing with this transfer process.

6. This diagram is taken from Jean-Claude Corbeil's paper "Problématique de la synonymie en vocabulaire spécialisén (in la Normalisation linguistique. Actes du Colloque international de terminologie, Lac Delage, Québec, octobre 1973, Québec, Office de la langue française, 1974, pp. 9-34), in which the author studies different types of relationships between the signifier, the signified and the referent. 
7. The important role played by polysemy in language is stressed by Maurice Pergnier (1980) in les Fondements sociolinguistiques de la traduction, Paris, Honoré Champion : "La polysémie, qui touche de manière plus ou moins importante toutes les unités de la langue, est en réalité (...) un fait central dans le mécanisme de la langue" (p. 181).

8. See Jean-Claude Corbeil, op. cit., p. 12.

9. Jean Dubois et al. use the principle of homonymy to organize entries in their Dictionnaire du français contemporain, (Paris, Larousse, 1976).

10. On this aspect, see Guy Rondeau (1981) : Introduction à la terminologie, Montréal, Centre éducatif et culturel, pp. $20,22$.

11. The ISO recommendation R704, Naming Principles (1968) presents, in section 3.3.1, criteria for determining which plurivalent terms are likely to be equivocal, along with examples that illustrate the application of these criteria and a recommendation to use different designations to cover different concepts in cases where the plurivalent term may be equivocal.

12. See Jean-Claude Corbeil, op. cit., p. 14.

13. See Robert Dubuc (1983) : "Synonymie et terminologie", in Problèmes de la définition et de la synonymie. Actes du Colloque international de terminologie, Québec, mai 1982, Québec, GIRSTERM, pp. $193-194$.

14. See Dorothy Nakos (1983) : "Synonymie et terminologie : point de vue complémentaire", in Problèmes de la définition et de la synonymie. Actes du Collogue international de terminologie, Québec, mai 1982, Québec, GIRSTERM, pp. 217-221.

15. While Vinay and Darbelnet originally used the term "transposition" in French, the concept covered by this French term has since been designated "transposition" in English as well. So it seems legitimate to discuss the synonymy of "transposition" and "level shift".

16. J.-C. Catford, in A Linguistic Theory of Translation (London, Oxford University Press, 1974, pp. 25-26) makes a distinction between "word-for-word translation" and "literal translation", but adds the generic term "rank-bound translation" to cover the general concept of translation sticking closely in form to the original.

17. See Jean Delisle (1980) : l'Analyse du discours comme méthode de traduction, Ottawa, University of Ottawa Press, pp. 69-86.

18. See Roda P. Roberts (1982) : "Le rôle du contexte et de la situation en traduction", in Actes du $2^{e}$ collogue sur l'enseignement du français fonctionnel et de la traduction en Amérique latine, Buenos Aires, INSP, pp. 180-192.

\section{SELECTIVE BIBLIOGRAPHY*}

BRISLIN, R.W. (1976) : "Introduction", in Translation. Applications and Research, ed. R.W. Brislin, New York, Gardiner Press, pp. 1-40.

CATFORD, J.C. (1974) : A Linguistic Theory of Translation, London, Oxford University Press.

DELISLE, J. (1980) : l'Analyse du discours comme méthode de traduction, Ottawa, University of Ottawa Press.

NIDA, E. \& C. TABER (1974) : The Theory \& Practice of Translation, Leiden, Brill.

PERGNIER, M. (1980) : les Fondements sociolinguistiques de la traduction, Paris, Honoré Champion.

ROBERTS, R.P. (1982) : "Le rôle du contexte et de la situation en traduction", in Actes du $2^{e}$ colloque sur l'enseignement du français fonctionnel et de la traduction en Amérique latine, Buenos Aires, INSA, pp. $180-192$.

SELESKOVITCH, D. (1976) : "Interpretation, a Psychological Approach to Translation", in Translation. Applications and Research, ed. R.W. Brislin, New York, Gardiner Press, pp. 92-116.

SELESKOVITCH, D. (1975) : Langage, langues et mémoire, Paris, Minard.

STEINER, G. (1977) : After Babel, London, Oxford University Press.

VINAY, J.-P. \& DARBELNET, J. (1958) : Stylistique comparée du français et de l'anglais, Paris, Didier.

* This bibliography includes only the works analyzed from the point of view of translation terminology.

RODA ROBERTS 